\title{
Socio-economic differentials in health: the role of nutrition
}

\author{
BY GEORGE DAVEY SMITH ${ }^{1}$ AND ERIC BRUNNER ${ }^{2}$ \\ ${ }^{1}$ Department of Social Medicine, Canynge Hall, Whiteladies Road, Bristol BS8 2PR \\ ${ }^{2}$ University College London Medical School, Department of Epidemiology and Public Health, \\ 1-19 Torrington Place, London WCIE 6BT
}

Mortality differentials according to socio-economic group have long been recognized in the UK. Engels (1845) reproduced such data, using both area-based and individual indicators of socio-economic status (Table 1). Engels (1845) went on to quote from the Report on the Sanitary Conditions of the Working Class: 'In Liverpool in 1840 the average life-span of the upper classes, gentry, professional men, etc, was thirty-five years; that of the business men and better-placed handicraftsmen, twenty-two years; and that of the operatives, day-labourers, and serviceable class in general, but fifteen years'.

To Engels (1845) it was obvious that deficiencies in nutrition contributed to the poor health of the labouring classes. The dependence of dietary adequacy on financial wherewithal was clear. 'The better paid workers, especially those in whose families every member is able to earn something, have good food as long as this state of things lasts; meat daily and bacon and cheese for supper. Where wages are less, meat is used only two or three times a week, and the proportion of bread and potatoes increases. Descending gradually, we find the animal food reduced to a small piece of bacon cut up with the potatoes; lower still, even this disappears, and there remain only bread, cheese, porridge, and potatoes, until on the lowest rung of the ladder, among the Irish, potatoes form the sole food'.

Engels (1845) recognized that the financial disadvantages of the poor were compounded by other social factors in determining their poor diet. The payment of wages on Saturday evening meant that workers could only buy their food after the middle class had had first choice during Saturday morning. When the workers reached the market, 'the best has vanished, and, if it was still there, they would probably not be able to buy it. The potatoes which the workers buy are usually poor, the vegetables wilted, the cheese old and of poor quality, the bacon rancid, the meat lean, tough, taken from old, often diseased, cattle, or such as have died a natural death, and not fresh even then, often half decayed'. The working classes were also more liable to be sold adulterated food, because while the rich developed sensitive palates through habitual good eating and could detect adulteration, the poor had little opportunity to cultivate their taste and were unable to detect adulteration. They also had to deal with small retailers who could not sell "even the same quality of goods so cheaply as the largest retailers, because of their small capital and the large proportional expenses of their business, must knowingly or unknowingly buy adulterated goods in order to sell at the lower prices required, and to meet the competition of the others'. The capitalist class, naturally, failed to acknowledge the poor health generated by the inadequate diet of the working class. Indeed, the philosopher of industrialization Andrew Ure was quoted by Engels (1845) as suggesting that the workers pampered themselves into nervous ailments 'by a diet too rich and exciting for their indoor employments'.

Engels was writing at a time when the mortality experience of the inhabitants of some of the great cities was worsening (Williams, 1994) and the decline in overall population 
mortality rates which had been occurring in Britain had ceased (Wrigley \& Schofield, 1981). From the 1860 s on, however, mortality rates tended to decline, first for children and young adults and then for older adults (Kuh \& Davey Smith, 1993). Infant mortality, interestingly, failed to decline until after the turn of the century. With only occasional reversals, seen, for example, among middle-aged men and women between 1920 and 1940, mortality rates have continued to decline (Davey Smith \& Marmot, 1991).

These major declines in mortality occurring during industrialization and economic growth have been attributed to improved nutrition by Thomas McKeown (1988), among others, although this view has been strongly challenged (Szreter, 1988; Johansson, 1994) on both empirical grounds and methodological grounds. However, these critiques, which take a broader view of developments in social policy, public health and medicine, have themselves been criticised (Guha, 1944).

The thesis that improvements in nutrition were responsible for the decline in mortality largely refers to adequate quantity of food, rather than specific dietary composition. Internationally, higher energy consumption is related to lower mortality rates, and there are plausible biological mechanisms for such an influence. Similarly, the maintenance of adequate nutrition between 1920 and the end of the Second World War may have prevented an interruption or reversal in the decline in infant mortality during this period of high unemployment (Winter, 1988). Elucidating the role of nutrition in other aspects of mortality trends is more problematic. It is often asserted that over-nutrition has led to the rise in the 'diseases of affluence', cancer and CHD (McKeown, 1988). However, the increase in cancer mortality was largely or entirely due to the rise in lung cancer, to which diet is unlikely to have contributed greatly. Some cancers which may plausibly be dietrelated, such as stomach cancer, declined in importance over this period. For CHD, the evidence relating mortality trends to diet is controversial. There are few data with which to examine trends in fat consumption and reviews have come to contradictory conclusions (Morris, 1956; Greaves \& Hollingsworth, 1966; Trenchard, 1977). There is no strong evidence of large increases in per capita total fat or saturated fatty acids consumed in the period leading up to the rise in CHD (Greaves \& Hollingsworth, 1966; Trenchard, 1977). As a percentage of energy consumed fat intake did increase in the expected way (Stephen \& Sieber, 1994; Johansson et al. 1996). It is postulated that a certain population mean level of serum cholesterol is required for CHD to become a mass disease (World Health Organization Expert Committee on Prevention of Coronary Heart Disease, 1982), and the diet prevalent by the middle of this century may have been sufficient to produce this. Other factors, also, will then have contributed to the rise in CHD against this background.

Table 1. Mortality ratios (no. of living people for each death) in Chorlton-on-Medlock, Manchester (From Engels, 1845)

\begin{tabular}{ccccc}
\hline & \multicolumn{3}{c}{ Class of house* } \\
\cline { 2 - 5 } & Class of street* & 1st & 2nd & 3rd \\
\hline 1st & 51 & 45 & 36 \\
2nd & 55 & 38 & 35 \\
3rd & $-\dagger$ & 35 & 25 \\
\hline
\end{tabular}

$* 1$ st class $=$ best; 3 rd class $=$ worst.

† No data. 


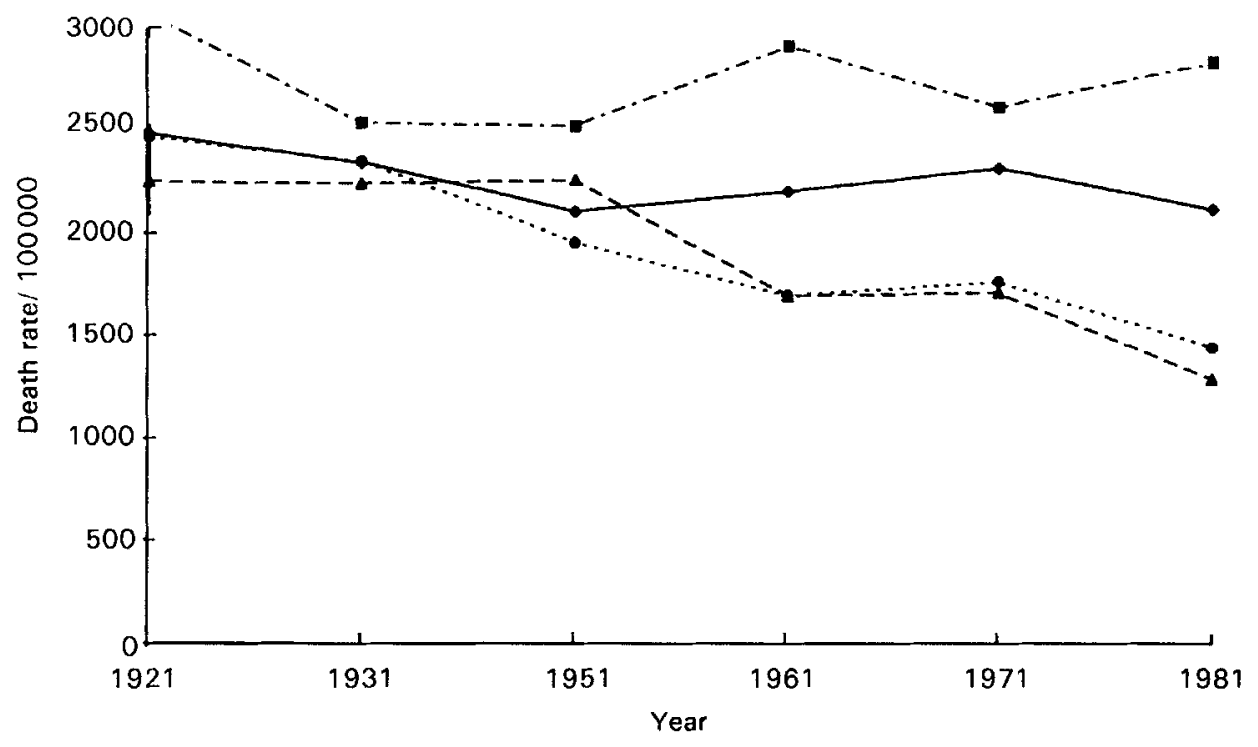

Fig. 1. Death rates per 100000 men aged 50-64 years in England and Wales, 1921-1981 in social class I (A), II (⿻), IV $(\bullet), \mathrm{Q}(\boldsymbol{a})$. (From Blane et al. 1997.)

\section{SOCIO-ECONOMIC DIFFERENTIALS IN HEALTH}

Socio-economic differentials in mortality have persisted from the time of Engels' (1845) description of early Victorian conditions until the present day (Davey Smith et al. 1990a, 1992; Davey Smith \& Morris, 1994). The production of statistics on social-class mortality differences at the time of each British census has provided the best longitudinal series of such data. Fig. 1 presents mortality rates for middle-aged men from the years relating to the 1921 census to the years relating to the 1981 census. Dramatic declines in mortality are seen for social classes I and II, while for social classes IV and V small and inconsistent decreases in mortality are seen. Increases in both the relative and absolute differentials in mortality between the social class groups have occurred since the early 1950s (Blane et al. 1997), a pattern which recent data demonstrate has continued throughout the $1980 \mathrm{~s}$ (Harding, 1995). Analyses based on the socio-economic characteristics of areas, rather than individuals, have demonstrated that while mortality rates have shown large decreases in affluent areas, rates have recently increased for some age-groups in the poorest areas (McCarron et al. 1994; Phillimore et al. 1994). Much of the adverse trend in mortality among the poorest groups is due to external causes. The relative and absolute increases in differentials shown in the area-based studies are clearly not due to changes in size of the groups under study and detailed analyses of the trends in the census-based data demonstrate that the same applies to these (Pamuk, 1985; Najman, 1993).

Reliable morbidity data are more difficult to locate than mortality data with regard to socio-economic differentials. A series of recent studies have demonstrated that common forms of morbidity demonstrate the same socio-economic patterning as does mortality (Marmot et al. 1991; Eachus et al. 1996). Table 2 displays the differing prevalences of various chronic conditions according to the socio-economic characteristics of area of 
Table 2. Age-standardized prevalence per 100 self-reported diseases by deprivation category* (From Eachus et al. 1996)

\begin{tabular}{|c|c|c|c|c|c|c|}
\hline $\begin{array}{l}\text { Quintile of deprivation... } \\
n \ldots \\
\text { Condition }\end{array}$ & $\begin{array}{c}1 \mathrm{st} \\
2597\end{array}$ & $\begin{array}{c}\text { 2nd } \\
2367\end{array}$ & $\begin{array}{c}\text { 3rd } \\
1624\end{array}$ & $\begin{array}{c}\text { 4th } \\
1696\end{array}$ & $\begin{array}{c}5 \text { th } \\
2024\end{array}$ & Test for trend: $P$ \\
\hline & \multicolumn{6}{|c|}{ Men } \\
\hline Musculoskeletal diseases & $14 \cdot 1$ & $15 \cdot 1$ & $16 \cdot 1$ & $16 \cdot 1$ & $17 \cdot 7$ & $<0.001$ \\
\hline Angina & 4.4 & $5 \cdot 5$ & 5.5 & 5.5 & 6.9 & $<0.001$ \\
\hline Myocardial infarction & $3 \cdot 2$ & 3.7 & 4.0 & 4.5 & 4.8 & $<0.001$ \\
\hline Asthma & $5 \cdot 6$ & $6 \cdot 1$ & $6 \cdot 2$ & $6 \cdot 4$ & $6 \cdot 4$ & 0.18 \\
\hline Bronchitis & $5 \cdot 2$ & $6 \cdot 3$ & $7 \cdot 3$ & 7.7 & 9.1 & $<0.001$ \\
\hline Depression & 3.9 & $4 \cdot 8$ & 5.9 & $6 \cdot 2$ & 6.9 & $<0.001$ \\
\hline Stroke & 2.0 & 1.8 & $1 \cdot 3$ & $2 \cdot 3$ & $2 \cdot 6$ & 0.03 \\
\hline \multirow[t]{2}{*}{ Diabetes } & $2 \cdot 4$ & $2 \cdot 5$ & $3 \cdot 7$ & $2 \cdot 7$ & $2 \cdot 1$ & 0.83 \\
\hline & \multicolumn{6}{|c|}{ Women } \\
\hline Musculoskeletal diseases & $27 \cdot 3$ & 28.6 & $30 \cdot 6$ & $30 \cdot 5$ & $34 \cdot 5$ & $<0.001$ \\
\hline Angina & 3.8 & $4 \cdot 4$ & $4 \cdot 6$ & $4 \cdot 4$ & 5.8 & $<0.002$ \\
\hline Myocardial infarction & 1.5 & 1.9 & 1.7 & 1.8 & 2.5 & 0.03 \\
\hline Asthma & 6.4 & $6 \cdot 2$ & $7 \cdot 5$ & 7.0 & 9.8 & $<0.001$ \\
\hline Bronchitis & 7.5 & $8 \cdot 1$ & 9.0 & 10.2 & 13.2 & $<0.001$ \\
\hline Depression & $10 \cdot 1$ & 10.5 & 11.4 & 12.5 & 12.7 & $<0.001$ \\
\hline Stroke & 1.6 & $2 \cdot 0$ & $2 \cdot 1$ & $2 \cdot 2$ & $2 \cdot 4$ & 0.04 \\
\hline Diabetes & $2 \cdot 6$ & 2.4 & $2 \cdot 1$ & $2 \cdot 1$ & 2.4 & 0.56 \\
\hline
\end{tabular}

*For quintiles of deprivation score, 5 th is the most deprived and $1 \mathrm{st}$ is the least deprived.

residence in a sample of more than 20000 men and women in Somerset and Avon. However, reliable data on trends in socio-economic differentials in morbidity are not available.

\section{INVESTIGATING THE ORIGINS OF SOCIO-ECONOMIC DIFFERENTIALS IN HEALTH}

Several studies have investigated the contribution of particular health-related behaviours and physiological risk factors to mortality differentials. In the first Whitehall study, considerable differences in mortality risk according to two socio-economic indicators, employment grade in the civil service and car ownership, were demonstrated (Fig. 2; Davey Smith et al. 1990b). While smoking behaviour was patterned such that the lower grade and non-car-owning civil servants were more likely to smoke than the higher grade and car-owning ones, the pattern of mortality differentials was identical among men who had never smoked (Fig. 3; Davey Smith \& Shipley, 1991; Davey Smith et al. 1994a). Cholesterol levels were higher among high-grade compared with low-grade civil servants in the late $1960 \mathrm{~s}$, when this study was established. Differences in cholesterol levels could not account, therefore, for the higher rates of CHD among the lower-grade employees. This can be taken to suggest that differences in dietary fat intake between grades were not responsible for the CHD mortality differentials. Indeed, simultaneous consideration of a range of risk factors, including smoking, blood pressure, cholesterol levels and prevalent cardio-respiratory disease, failed to account for the grade differences in cardiovascular and non-cardiovascular mortality (Davey Smith et al. 1990b).

Similar findings have emerged from a study in the west of Scotland established about the same time as the first Whitehall study (Davey Smith et al. 1994b, 1997). Large differentials in CHD mortality according to both educational attainment and social class 


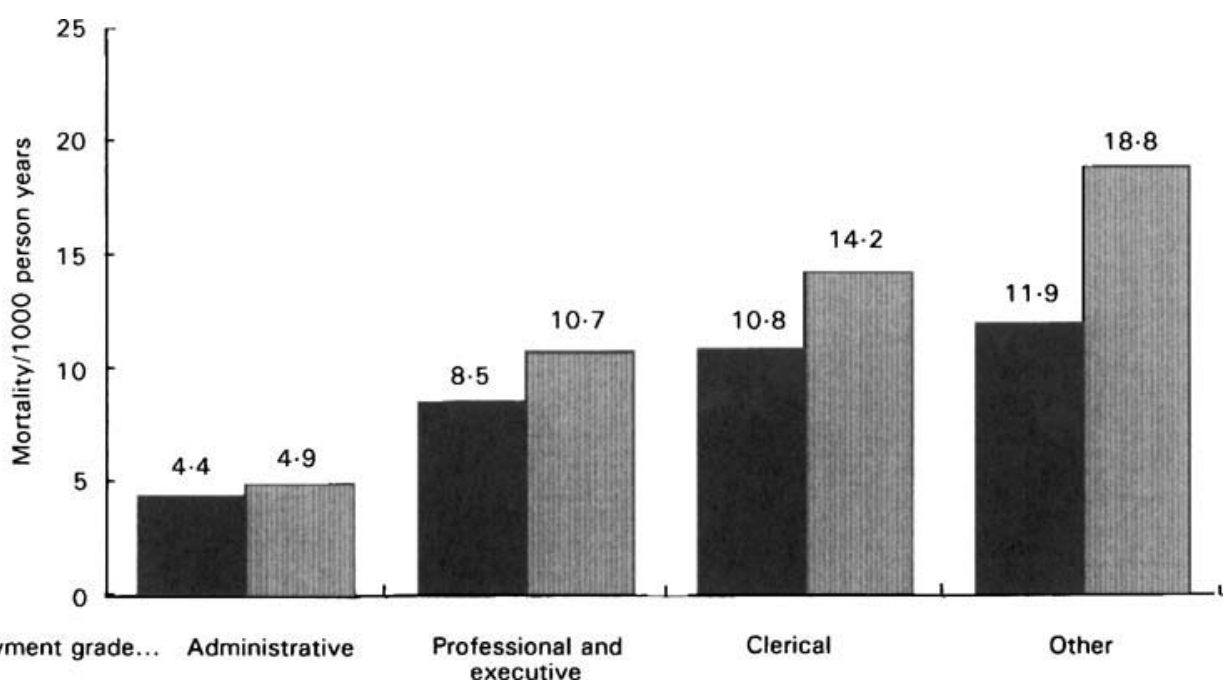

Fig. 2. Mortality by civil service employment grade and car ownership in the Whitehall study. ( $\square$ ), Car owner; ( $\square$ ), non-car owner. (From Davey Smith et al. 1990b.)

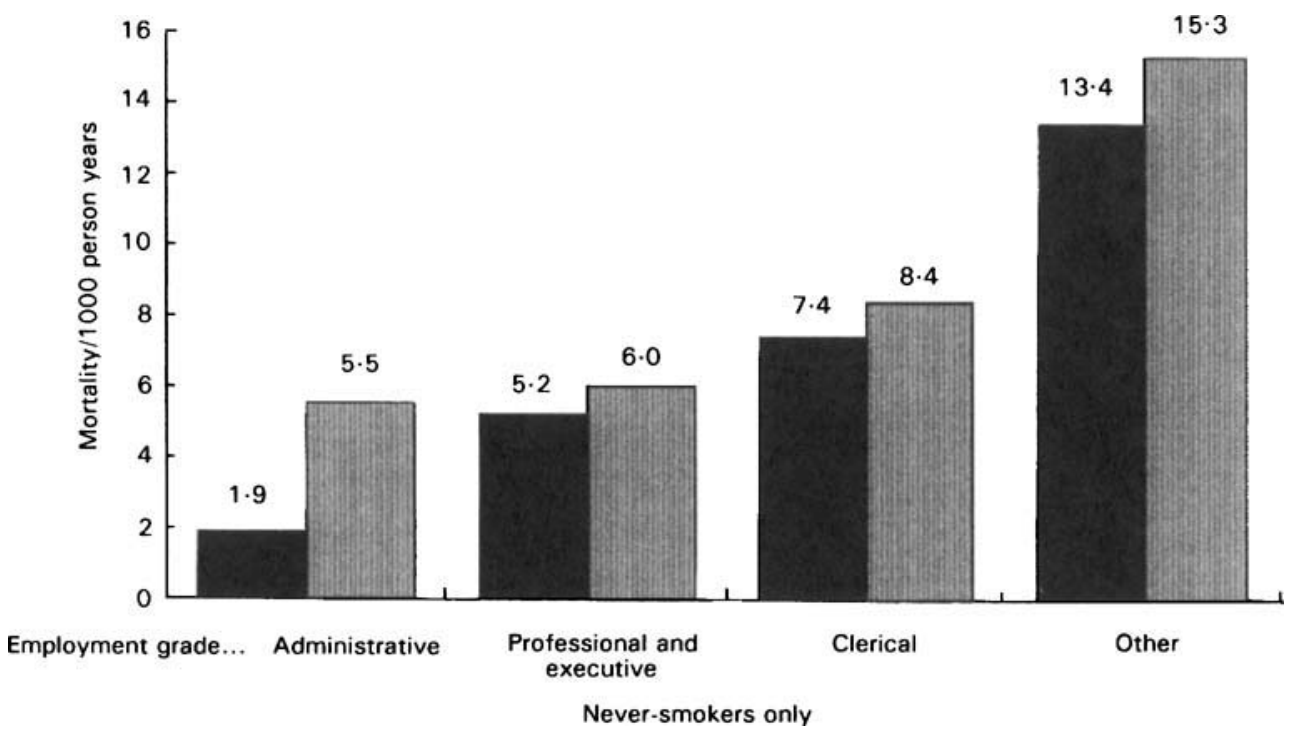

Fig. 3. Mortality by civil service employment grade and car ownership amongst never-smokers in the Whitehall study. (1), Car owner; ( 0 ), non-car owner. (From Davey Smith et al. 1990b.)

existed at a time when blood cholesterol levels were highest in those with the most education and in the professional and managerial classes. Adjustments for a wide range of risk factors failed to explain the considerable mortality differentials from major causes of death in this study.

As a result of such findings, the Whitehall II cohort was established in 1985 to investigate additional, particularly dietary, metabolic and psychosocial, factors which 
Table 3. Odds ratios (OR) with $95 \%$ Cl for occupying the top quintile of metabolic-syndrome variables in lowest $\mathrm{v}$. highest Civil Service employment grade; adjusted for age, and menopausal status in women (From Brunner et al. 1993b)

\begin{tabular}{|c|c|c|c|c|c|c|}
\hline \multirow[b]{2}{*}{ Variable } & \multicolumn{2}{|c|}{ Men } & \multirow[b]{2}{*}{ Test for trend } & \multicolumn{2}{|c|}{ Women } & \multirow[b]{2}{*}{ Test for trend } \\
\hline & OR & $95 \% \mathrm{CI}$ & & $\mathrm{OR}$ & $95 \% \mathrm{CI}$ & \\
\hline Metabolic syndrome ${ }^{\dagger}$ & 2.87 & 1.94 .4 .24 & $* * *$ & 2.03 & $1.03-4.04$ & $*$ \\
\hline Waist : hip ratio & 2.23 & $1 \cdot 76-2 \cdot 82$ & $* *$ & 1.58 & $1.08-2 \cdot 31$ & * \\
\hline BMI & 1.62 & $1.28-2.04$ & $* * *$ & 1.52 & $1.05-2.21$ & $*$ \\
\hline Systolic blood pressure & 1.22 & $0.97-1.52$ & NS & $1 \cdot 12$ & $0.78-1.60$ & NS \\
\hline $2 \mathrm{~h}$ post-load glucose & 1.65 & $1.30-2.09$ & $* * *$ & 1.81 & $1.23-2.68$ & $* *$ \\
\hline $2 \mathrm{~h}$ insulint & 1.43 & $1.09-1.89$ & $*$ & 1.50 & $0 \cdot 95-2 \cdot 38$ & 0.08 \\
\hline HDL-cholesterol\$ & 1.92 & $1.51-2.42$ & $* * *$ & $3 \cdot 02$ & $2 \cdot 02-4.51$ & $* *$ \\
\hline LDL-cholesterol & 0.99 & $0.77-1.26$ & NS & 1.50 & $1.01-2 \cdot 25$ & * \\
\hline Triacylglycerols & 1.55 & $1.23-1.96$ & $* *$ & $2 \cdot 14$ & $1.42-3.23$ & $* *$ \\
\hline Fibrinogen & 1.72 & $1 \cdot 34-2 \cdot 19$ & $* * *$ & 2.02 & $1.35-3.02$ & $* * *$ \\
\hline
\end{tabular}

NS $P>0.1, * P<0.05, * * P<0.005, * * * P<0.0001$.

$\dagger A$ subject is defined as having the metabolic syndrome if three or more of the following variables are in the leastfavourable quintile: waist : hip ratio, systolic blood pressure, 2 h post-load glucose, HDL-cholesterol, triacylglycerols.

$\ddagger$ Normoglycaemic subjects only.

$\S$ Bottom quintile.

might contribute to the social gradients in CHD risk (Marmot et al. 1991). The Whitehall II study found inverse gradients in prevalent electrocardiogram abnormalities in both sexes at baseline, which paralleled the findings in the original cohort. In this more recent study mean total cholesterol levels again appeared not to contribute to the occupational gradient in CHD risk. In both sexes, the mean cholesterol level at baseline was similar in each grade. Concentrations of serum apolipoprotein AI, the main structural protein of HDLcholesterol, did show an association with grade (Brunner et al. 1993a) and suggested that characteristic disturbances of metabolism associated with lower occupational status were potentially identifiable.

\section{SOCIAL CLASS, CENTRAL OBESITY AND METABOLISM}

The second examination of the Whitehall II cohort provides evidence of a distinctive socially-patterned clustering of risk factors (Brunner et al. 1993b). Central or male-type obesity, long recognized as a factor predisposing to diabetes and coronary disease (Vague, 1956) in both sexes, is linked with glucose intolerance, insulin resistance and disturbances of lipoprotein metabolism (low HDL-cholesterol and high fasting serum triacylglycerols among young blacks and whites in the U.S.A. (Folsom et al. 1989) and South Asians in the U.K. (McKeigue et al. 1991). Each of these components of the metabolic or insulinresistance syndrome, although not blood pressure, showed a close inverse relationship with employment grade in the Whitehall II study (Table 3). Clustering of risk factors into the characteristic metabolic-syndrome pattern was strongly associated with lower grade, particularly among men. Morbidity and mortality follow-up may prove this clustering to contribute to the biological explanation of social inequalities in cardiovascular risk.

The contribution of overall degree of obesity to the socio-economic differential in heart disease is unclear, but probably is increasingly relevant. Overweight is increasing in European and American adults in general (Kuczmarski et al. 1994; Nutrition and Physical 
Table 4. BMI and prevalence of obesity in civil servants in each employment grade in the Whitehall studies; age adjusted (40-59 years) (From Brunner et al. 1993b)

(Mean values with their standard errors)

\begin{tabular}{|c|c|c|c|c|c|c|c|}
\hline \multirow[t]{2}{*}{ Employment grade... } & \multicolumn{2}{|c|}{ Administrative } & \multicolumn{2}{|c|}{$\begin{array}{l}\text { Professional and } \\
\text { executive }\end{array}$} & \multicolumn{2}{|c|}{ Clerical and support } & \multirow{2}{*}{$\begin{array}{l}\text { Test for } \\
\text { trend: } P\end{array}$} \\
\hline & Mean & SE & Mean & $\mathrm{SE}$ & Mean & SE & \\
\hline \multicolumn{8}{|l|}{ Mean BMI $\left(\mathrm{kg} / \mathrm{m}^{2}\right)$} \\
\hline \multicolumn{8}{|l|}{ Whitehall } \\
\hline $\begin{array}{l}\text { Men } \\
\quad n \\
\text { Whitehall II (phase 3) }\end{array}$ & $\begin{array}{l}24 \cdot 5 \\
889\end{array}$ & 0.09 & $\begin{array}{l}24 \cdot 7 \\
11081\end{array}$ & 0.03 & $\begin{array}{l}24 \cdot 7 \\
3232\end{array}$ & 0.06 & 0.15 \\
\hline $\begin{array}{l}\text { Men } \\
n\end{array}$ & $\begin{array}{l}25 \cdot 0 \\
2404\end{array}$ & 0.06 & 2300 & 0.07 & $\begin{array}{c}25 \cdot 5 \\
334\end{array}$ & 0.22 & $<0.005$ \\
\hline $\begin{array}{c}\text { Women } \\
n\end{array}$ & $\begin{array}{l}24 \cdot 5 \\
352\end{array}$ & 0.24 & $\begin{array}{l}25 \cdot 4 \\
1006\end{array}$ & $0 \cdot 14$ & $\begin{array}{l}26 \cdot 5 \\
821\end{array}$ & $0 \cdot 19$ & 0.0001 \\
\hline \multicolumn{8}{|c|}{ Prevalence of obesity (BMI $>30 \mathrm{~kg} / \mathrm{m}^{2} ; \%$ ) } \\
\hline \multicolumn{8}{|l|}{ Whitehall } \\
\hline $\begin{array}{r}\text { Men } \\
n\end{array}$ & $\begin{array}{l}1 \cdot 7 \\
889\end{array}$ & 0.33 & $11081^{1.9}$ & 0.09 & $3232^{3 \cdot 1}$ & $0 \cdot 23$ & $<0.001$ \\
\hline \multicolumn{8}{|l|}{ Whitehall II (phase 3) } \\
\hline $\begin{array}{r}\text { Men } \\
n\end{array}$ & $2404^{6 \cdot 6}$ & 0.51 & $\begin{array}{l}7 \cdot 6 \\
2300\end{array}$ & 0.56 & $\begin{array}{l}10 \cdot 1 \\
334\end{array}$ & 1.65 & $<0.05$ \\
\hline $\begin{array}{c}\text { Women } \\
n\end{array}$ & 352 & 1.78 & 1006 & $1 \cdot 11$ & $\begin{array}{l}18.8 \\
821\end{array}$ & 1.48 & $<0.005$ \\
\hline
\end{tabular}

Activity Task Forces, 1995) and data from the two successive Whitehall cohorts illustrate that both overweight and obesity appear to have become more strongly linked with lower socio-economic status in the past 30 years. Mean BMI was within the normal weight category $\left(20-25 \mathrm{~kg} / \mathrm{m}^{2}\right)$ and similar in each employment grade in male Civil Servants screened in the late 1960 s (Table 4). In the second cohort, examined in the early 1990s, mean BMI is in the overweight category except in the administrative grade, and mean BMI is higher in the clerical grade in both sexes. The prevalence of obesity (BMI $>30 \mathrm{~kg} / \mathrm{m}^{2}$ ) increased markedly in the intervening period (Table 4). Obesity in the second cohort is more common in the lower grades in both sexes, and as might be expected, is very strongly linked with the prevalence of the metabolic syndrome (Brunner et al.1993b).

\section{SOCIAL PATTERNING OF DIET AND NUTRITION}

The 1986-7 Dietary and Nutritional Survey of British Adults (Gregory et al. 1990), in which a representative sample of the adult population of England, Wales and Scotland, completed a $7 \mathrm{~d}$ weighed-intake record, demonstrates a range of socio-economic differentials in dietary intake (Table 5).

Men in manual occupations reported higher intakes of dietary energy, presumably reflecting higher levels of physical activity. This finding has been seen elsewhere (Fehily $e t$ al. 1984). In contrast, women in non-manual occupations reported higher energy intakes than those in manual occupations. This may be an artifact of differential rates of dietary under-reporting according to social class (Pryer et al. 1995). Mean total and saturated fatty acid intakes, as a proportion of dietary energy, were not associated with social class in the British survey (Gregory et al. 1990). The mean polyunsaturated:saturated fatty acids (P:S) 
Table 5. Socio-economic differentials in diet from the Dietary and Nutritional Survey of British Adults 1986-7 (Gregory et al. 1990)

\begin{tabular}{llcc}
\hline & \multicolumn{2}{c}{$\begin{array}{c}\text { Associations by social class of } \\
\text { head of household }\end{array}$} \\
\cline { 2 - 3 } & Men & Women \\
\hline Energy & Inverse & Direct \\
Alcohol & Heterogeneous & Direct \\
Sugars & Direct & NS \\
Fibre & NS & Direct \\
Total fat and saturated fatty acids & NS & NS \\
Polyunsaturated: saturated fatty acids & Direct & Direct \\
Ca, Fe, Mg, K,P & Direct & Direct \\
Vitamins A,B,C & Direct & Direct \\
\hline \hline
\end{tabular}

Table 6. Mean intakes of nutrients and intakes (\% dietary reference values ${ }^{*}$ ) by income support (IS) receipt for UK female lone-parents (n 126) (From Dowler \& Calvert, 1995)

(Values are arithmetic mean of \% dietary reference value, except for fat and NSP ( $g / d$ ) with their standard errors. Geometric means are given for vitamins $\mathrm{C}, \mathrm{A}$ and $\mathrm{E}$ )

\begin{tabular}{|c|c|c|c|c|c|}
\hline \multirow[b]{2}{*}{ Nutrient } & \multicolumn{2}{|c|}{ IS $(n 85)$} & \multicolumn{2}{|c|}{ No IS ( $n 41)$} & \multirow{2}{*}{$\begin{array}{l}\text { Statistical significance of } \\
\text { difference by ANOVA: } P\end{array}$} \\
\hline & Mean & SE & Mean & SE & \\
\hline Energy: kcal & 1743 & 55 & 1895 & 85 & NS \\
\hline $\mathrm{MJ}$ & 7.3 & 0.23 & 7.9 & 0.36 & NS \\
\hline$\%$ EAR & 84 & 2.8 & 88 & 3.6 & NS \\
\hline Protein (\% RNI) & 144 & 4.8 & 154 & 7.4 & NS \\
\hline Fat, total $(\mathrm{g})$ & 77 & 2.8 & 81 & 4.8 & NS \\
\hline NSP: Total (g) & 9.7 & 0.45 & $12 \cdot 3$ & 0.9 & 0.004 \\
\hline$\%$ EAR & 54 & 2.5 & 68 & 4.8 & 0.004 \\
\hline Fe $(\%$ RNI $)$ & 65 & 2.7 & 89 & 6.2 & 0.0001 \\
\hline Folate (\% RNI) & 90 & $4 \cdot 3$ & 107 & 7.4 & 0.032 \\
\hline $\mathrm{Ca}(\% \mathrm{RNI})$ & 98 & 4.8 & 103 & 5.8 & NS \\
\hline $\mathrm{Zn}(\% \mathrm{RNI})$ & 107 & 4.4 & 118 & 6.8 & NS \\
\hline Vitamin A (\% RNI) & 96 & + & 129 & $\dagger$ & NS \\
\hline Vitamin C (\% RNI) & 94 & $\dagger$ & 155 & + & 0.005 \\
\hline Vitamin E (\% safe intake) & 162 & $\dagger$ & 206 & + & 0.018 \\
\hline
\end{tabular}

RNI, reference nutrient intake; EAR, estimated average requirement.

*Department of Health (1991).

$\dagger$ No standard errors were presented; results were expressed as geometric means.

ratio did vary according to social class with men and women in higher social strata tending to report a higher P:S ratio These findings suggest that amount of total fat and dietary saturated fatty acids may not play a major role in the excess coronary risk among adults of lower social status, while polyunsaturated fatty acid intake may be important. This interpretation is supported by the findings (Braddon et al. 1988) of the National Survey of Health and Development (the 1946 birth cohort), from a $7 \mathrm{~d}$ diet diary completed in 1982 , which show that saturated fatty acid intake did not vary by education level among men. Among women it was highest in those with university education.

Although fat intakes appeared to be weakly associated with social position among adults in the $1980 \mathrm{~s}$, the micronutrient density of the diet differed markedly by social class. Vitamins $\mathrm{A}, \mathrm{B}$ and $\mathrm{C}$, and $\mathrm{Fe}, \mathrm{Mg}, \mathrm{K}, \mathrm{Ca}$ and $\mathrm{P}$ were all present at higher levels in diets of 
those in higher social classes. Congruent findings have come from a study of nutrient intakes in lone-parent households (Dowler \& Calvert, 1995). Intakes were compared for lone-mothers in relation to whether they received income support or not. The average weekly income in households claiming income support was $£ 87$ in this study; for those not claiming income support it was $£ 226$ (Table 6). The data on social differences in nutrition (similar fat intakes, but large differentials in micronutrient density) point to a social influence on food consumption patterns. These are the product of a diverse combination of economic, cultural and personal factors.

Diet, therefore, in the main way it is currently believed to increase CHD risk, does not appear to contribute greatly to the direction or the trends in social-class differentials in CHD. Evidence from other studies points to the same conclusion (Cade et al. 1988; Morgan et al. 1989). Instead, the British data point to micronutrient and antioxidant intakes as the most likely nutritional influences on health inequalities. It appears to be sociallypatterned differences in food sources which determine the differences in micronutrient density observed.

Several studies have demonstrated that Engels' (1845) conclusions remain applicable today: those least able to purchase a healthy diet due to financial constraints are those most likely to be disadvantaged with regard to access to healthy micronutrient-dense food. Thus, a shopping-basket survey in Glasgow demonstrated that households in a less-economicallyfavoured area paid more for a healthy basket of food than households in a more-favoured area, while there was no difference in the cost of an unhealthy basket of food. It was also noted that several items of the healthy food basket were simply not available in the lessfavoured area (Sooman et al. 1993). A similar survey was carried out in London in 1988 and repeated in 1995. At both times healthy food was more expensive in the deprived area while unhealthy food was slightly cheaper in the deprived area (Lobstein, 1995). This study suggested that the situation for those living in the deprived area had become relatively worse between 1988 and 1995.

Poorer families have been disadvantaged by changes in food retailing. Between 1980 and 1992 the number of food retail outlets decreased by $35 \%$ (Department of Health, 1996). This reflects a decline in the number of small grocery retailers and specialist shops, including butchers and greengrocers, and an increase in large supermarkets. Such large retailers tend to be based outside towns and customers require transport to them. The low rate of car ownership among poorer households makes it difficult for them to utilize these generally cheaper outlets. In essence, the transfer of food retailing from smaller local retailers to large out-of-town superstores represents a transfer of costs from the food wholesaler, who is required to transport food to fewer outlets, to the customer, who must travel further to purchase food. This transfer represents a disproportionate burden to poorer households and contributes to widening inequalities in material circumstances.

Low-income households, residing in less-affluent areas, are disadvantaged in other ways with respect to food, diet and nutrition. Such households may especially value the social resource represented by the personal nature of local shopping, given fewer alternative social opportunities. Shopping can become a demoralising experience for those whose choice is constrained by a lack of income (Dowler, 1996). The costs of cooking and of stocking essential items required for food preparation represent additional expenditure which may not be available in less-well-off households. Thus, the use of convenience foods or items such as sandwiches which require no cooking is encouraged.

In a detailed ethnographic study of the social organization of nutritional inequalities Travers (1996) concluded that 'The public discourse most consistent with the findings and experience of this research was apparently informed by an individualistic ideology. 
Individualism assumes that the current social system provides sufficient and equal opportunity for individuals to move within the social system according to their abilities. Within this ideological construct, poverty results from the individual's failure to seize the opportunity or to work sufficiently hard within the current social structure; it is not a reflection of inadequacies and inequities within that social order'. This need not go unchallenged, however. The women in Travers (1996) study were aware that inequitable pricing policies existed, such that the more expensive food stores are located in the innercity, closer to the areas of residence of socially- and economically-disadvantaged households. The women initiated a letter-writing campaign to supermarket managers which resulted in a reduction in the pricing differentials between inner-city and suburban stores.

\section{LIFE-COURSE INFLUENCES ON HEALTH INEQUALITIES}

Until recently the debates regarding inequalities in health generally related to the association between socio-economic circumstances in adulthood and poor health. There has recently been a revival of interest in the effects of poor social circumstances in early life on health in adulthood (Kuh \& Davey Smith, 1993). The UK Department of Health (1995) report, Variations in Health has recognized the importance of a life-course perspective on inequalities in health. It concludes that it is likely that accumulative differential lifetime exposure to health-damaging or health-promoting physical and social environments is the main explanation for observed variations in health and life expectancy'. However, few empirical data regarding such cumulative effects exist. In a cohort study in which men have been followed for over 20 years in the west of Scotland (Hart et al. 1995; Davey Smith et al. 1997), it was possible to relate mortality experience to the social class of the men's fathers, to the social class of their first occupation on entering the labour market; and to the social class of their occupation at the time of screening, when aged 35-64 years. In Table 7 it is demonstrated that cumulative social class, together with indicators of socio-economic position at the time of screening, are strongly related to mortality risk. When social class at different periods of the life-course is related to mortality from specific causes it is seen that the social class of the fathers of the men and their own social class at the time of screening independently contribute to all-cause and

Table 7. All-cause mortality (age-adjusted relative rates) by cumulative social class*, car access and deprivation category $\dagger$ in a cohort study of men followed for over 20 years in the west of Scotland (From Davey Smith et al. 1994b; Hart et al. 1995; Davey Smith et al. 1997)

\begin{tabular}{lcccc}
\hline \hline Cumulative social class $\ldots$ & $\begin{array}{c}\text { All three } \\
\text { non-manual }\end{array}$ & $\begin{array}{c}\text { Two non-manual } \\
\text { and one manual }\end{array}$ & $\begin{array}{c}\text { Two manual and } \\
\text { one non-manual }\end{array}$ & All three manual \\
\hline Car & 1 & 1.28 & 1.36 & 1.57 \\
No car & 1.22 & $\begin{array}{c}(1.01-1.63) \\
1.52\end{array}$ & $\begin{array}{c}(1.08-1.73) \\
1.76\end{array}$ & $\begin{array}{c}(1.27-1.95) \\
2.00\end{array}$ \\
& $(0.91-1.64)$ & $(1.19-1.95)$ & $(1.40-2.21)$ & $(1.64-2.44)$ \\
Deprivation category 1-4 & 1 & 1.25 & 1.37 & 1.70 \\
Deprivation category 5-7 & 1.06 & $(1.01-1.56)$ & $(1.09-1.72)$ & $(1.39-2.09)$ \\
& $(0.74-1.52)$ & $(1.10-1.82)$ & $(1.25-1.90)$ & $(1.45-2.09)$ \\
\hline
\end{tabular}

\footnotetext{
* Summation of social class locations at three stages of the life-course: father's social class, own social class at labour market entry; own social class in middle age.

$\dagger$ Carstairs deprivation index categories based on census variables: $1-4$, more affluent areas; 5-7, more deprived areas.
} 
cardiovascular disease mortality. This suggests that there are some long-lasting influences of socio-economic circumstances in childhood on mortality in adulthood. The suggestion that mortality risk reflects the accumulation of environmental insults or the cumulative effects of unfavourable behavioural or psychological factors which progressively increase susceptibility to disease (Jones, 1956; Alter \& Riley, 1989) is also supported by a study based on record linkage of the 1960, 1970 and 1980 census records for Norway, in which particularly high mortality risks are seen among men who obtain limited education and then go on to work in manual occupations and live in poor housing (Salhi et al. 1995). Similar findings have come from the US national longitudinal study of older men (Mare, 1990). The particular dependence of cardiovascular disease risk on childhood socioeconomic circumstances in comparison with other causes of death has been observed in area-based studies from Finland (Valkonen, 1987; Koskinen, 1994).

A nutritional factor which may contribute to the life-course accumulation of disease risk is that of fruit and vegetable intake (Rimm et al. 1996). In a study of Finnish men (Lynch et al. 1996) intakes of fruit, non-root vegetables and vitamin C were related to childhood socio-economic circumstances, implying that this adult dietary behaviour may become established early in life and not be readily amenable to change at a later stage.

Of particular current research interest are the long-term effects of development during fetal and early infant life on disease risk in adulthood. A series of ecological and prospective studies have demonstrated that birth weight and weight at 1 year of age are inversely related to cardiovascular disease risk, diabetes risk and blood pressure in later life (Barker, 1995). While it is difficult to separate out the effects of such early life exposures from later experiences (Ben-Shlomo \& Davey Smith, 1991; Bartley et al. 1994), these findings are strongly suggestive of important persisting influences from early life into adulthood. Although nutrition over the life-course is an important consideration, there is evidence in the case of cardiovascular disease that early influences may also manifest themselves in adulthood through effects which are at most only weakly related to diet. The haemostatic risk factor, plasma fibrinogen, is raised among smokers and in obesity and reduced by moderate alcohol consumption, but is not known to be directly influenced by diet. In Whitehall II data (Brunner et al. 1996) adult fibrinogen level showed a strong inverse relationship with father's social class and level of education, as well as with adult occupational status.

Less research has been carried out recently on the effects of childhood nutrition on later disease, although earlier this century it was considered unproblematically obvious that such effects did exist (Davey Smith \& Kuh, 1996). Preliminary data are now available from a mortality follow-up of the children included in surveys of poverty, nutrition and child health carried out under the auspices of Lord John Boyd Orr in the immediate pre-Second World War period (Rowett Research Institute, 1955). At the time this survey was carried out it was recognized by one of the investigators that leg length was a particularly good indicator of childhood socio-economic and nutritional circumstances:

'When the Carnegie UK Dietary and Clinical Survey was planned at the Rowett Research Institute in 1937, cristal height as a measure of leg length was included in the measurements... it was found that cristal height was consistently better than total height for indicating expenditure group... we find the longer-legged children suffered less bronchitis than the short at all ages. Since there is neither complicating immunity mechanism nor specific cure for bronchitis, we might argue that constitution built up when the complete harmonious pattern of growth is unfolded is, in some way, superior to that associated with inhibition of growth, however slight.' (Leitch, 1951). 
Table 8. Pearson's correlation coefficients between anthropometry, childhood dietary and socio-economic variables among boys in the Carnegie survey (From Gunnell et al. 1996)

\begin{tabular}{lcrrr}
\hline & & \multicolumn{3}{c}{ ' $z$ ' score for } \\
\cline { 5 - 5 } Anthropometric, dietary or socio-economic index & $n$ & Height & Leg length & Trunk length \\
\hline Birth order & 1397 & $-0.14^{*}$ & $-0.14^{*}$ & $-0.06^{*}$ \\
No. of children in household & 1394 & $-0.25^{*}$ & $-0.24^{*}$ & $-0.14^{*}$ \\
Weighted per capita food expenditure & 1394 & $0.31^{*}$ & $0.33^{*}$ & $0.14^{*}$ \\
Social class of head of household & 1287 & $-0.18^{*}$ & $-0.21^{*}$ & -0.05 \\
Overcrowding & 1220 & $-0.19^{*}$ & $-0.20^{*}$ & $-0.08^{*}$ \\
Relative family per capita energy consumption & 1394 & $0.23^{*}$ & $0.26^{*}$ & $0.08^{*}$ \\
\hline \hline
\end{tabular}

$* P<0.05$.

In a re-analysis of these data this is clearly the case (Gunnell et al. 1996; Table 8). Age-standardized indicators of total height, leg length and trunk length reveal differential associations with nutritional and socio-economic factors. In particular, it is noticeable that the negative correlations between overcrowding and social class of head of household (scored from 1 for professional groups to 5 for unskilled manual workers) are considerably stronger for leg length than for trunk length, while the positive correlations between weighted per capita food expenditure and relative family per capita energy consumption are similarly stronger for leg length than trunk length. Results for females are similar to those in males.

Leg length in childhood is associated with mortality over the subsequent 60 years (Table 9). These data suggest that there may be important long-term consequences of childhood nutrition on health in later life. However, they do not paint a one-sided view of

Table 9. Leg length and mortality: Carnegie survey follow-up (From Gunnell et al. 1996)

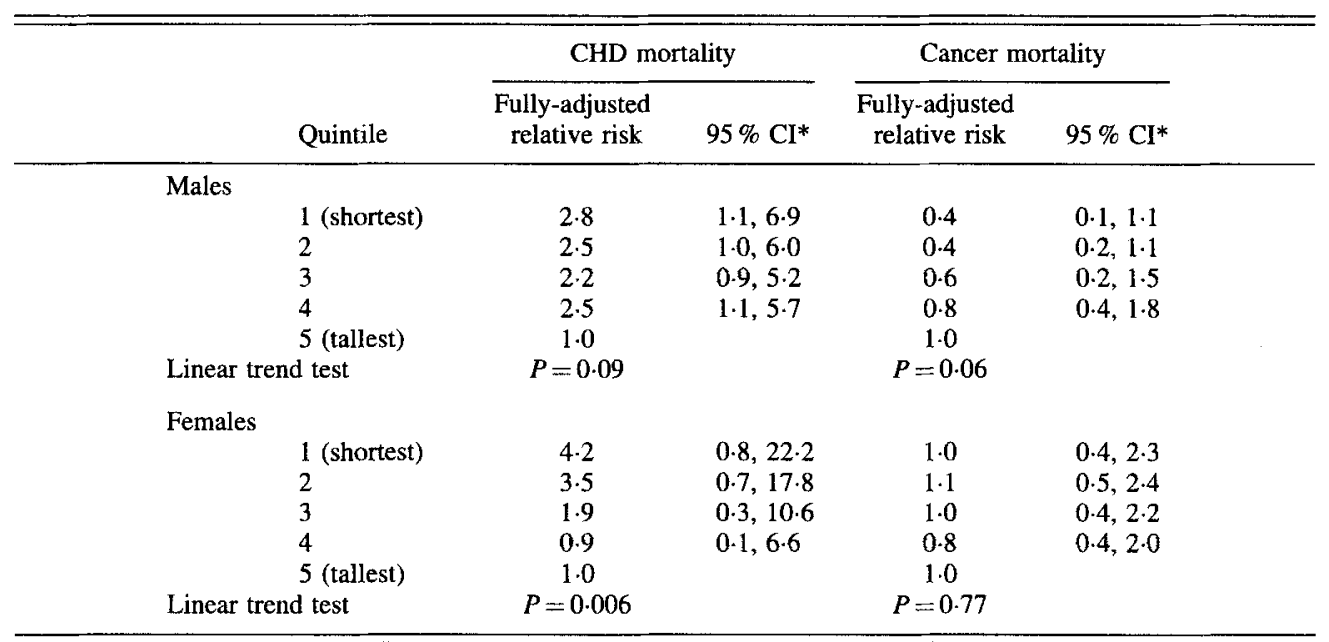

*Adjusted for age and indices of childhood and adult socio-economic circumstances, energy consumption and birth order. 


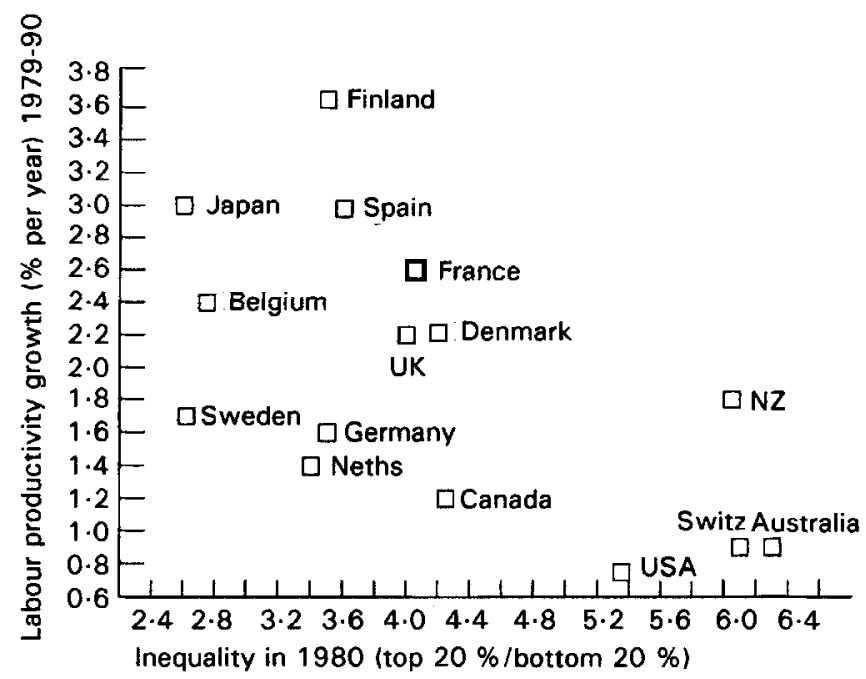

Fig. 4. Income inequality in 1980 and labour productivity growth between 1979 and 1990 . Neths, Netherlands; Switz, Switzerland; NZ, New Zealand. (From Glynn \& Miliband, 1994.)

rapid growth in childhood. In line with evidence from animal studies and some epidemiological findings (Tannenbaum, 1947; Albanes et al. 1988), they suggest that cancer risk may be increased by greater energy intake and growth in early life. Thus, reductions in cardiovascular-disease mortality in response to socio-economic and nutritional conditions which encourage growth in childhood may, in part, be counterbalanced by increases in cancer mortality. Studies which obtain data over the life-course of participants are required to untangle the relative contributions of factors acting at different stages of life and to understand the importance of interactions between such factors across the life-course in generating disease risk in adulthood.

\section{CONCLUSIONS}

The precise role of nutrition in generating inequalities in health is difficult to delineate. However, this does not mean that action should await the outcome of further research. In several cases it is clear that nutritional deficiencies or excesses which will generate health problems are socially patterned in such a way as to further disadvantage the poor. Examples include Fe-deficiency anaemia in children, lower breast-feeding rates among the less-advantaged, poor birth outcomes in response to inadequate maternal diet and inadequate vitamin and mineral intake by adolescents (Department of Health, 1996). These social variations in nutritional adequacy cannot be countered by simple health education messages since structural constraints clearly mitigate against their adoption. Innovative programmes which work with low-income communities, however, can lead to improvements (James, 1995; Dowler, 1996).

The fundamental cause of socio-economic differentials in health remains the level of inequality in material resources within a society (Davey Smith et al. 1994a). This is well illustrated by recent trends in mortality differentials and income differentials within the UK. Area-based studies and prospective follow-up of a general population sample from the census have demonstrated that mortality differentials have increased over the last $15-20$ 
years (Phillimore et al. 1994; McCarron et al. 1994; Harding, 1995). Over the same time period many indicators reveal increasing social polarization. By 1993 one in three children in the UK lived in households with less than $50 \%$ of average UK income after housing costs; in 1979 this was less than one in ten (Child Poverty Action Group, 1996). Income inequalities have increased enormously over the same period, with the income after housing costs of the lowest decile group in 1991 being lower than the equivalent income of the lowest decile group in 1979 (Davey Smith \& Egger, 1993).

The only economic argument in support of allowing income inequalities to widen is that the incentive of large income increases for the already wealthy in some way drives overall economic performance. This doctrine, strongly associated with the Thatcherite agenda of the 1980 s, has recently been exploded. Fig. 4 plots labour productivity growth between 1979 and 1990 against income inequality in 1980. It is clear that countries with lower levels of income inequality in 1980 had greater labour productivity growth over the following decade. In 1979, the UK lay at about the average of the countries under consideration for both income inequality and labour productivity growth. Since then inequality has massively increased in the UK and it is now vying with the USA for the unfavourable title of most unequal country.

\section{REFERENCES}

Albanes, D., Jones, D. Y., Schatzkin, A., Micozzi, M. S. \& Taylor, P. R. (1988). Adult stature and risk of cancer. Cancer Research 48, 1658-1662.

Alter, R. \& Riley, J. (1989). Frailty, sickness and death: Models of morbidity and mortality in historical populations. Population Studies 43, 25-46.

Barker, D. J. P. (1995). Early nutrition and coronary heart disease. In Nutrition in Child Health, pp. 77-85 [D. P. Davies, editor]. London: Royal College of Physicians of London.

Bartley, M., Power, C., Blane, D., Davey Smith, G. \& Shipley, M. J. (1994). Birthweight and later socioeconomic disadvantage: evidence from the 1958 British cohort study. British Medical Journal 309, 14751478 .

Ben-Shlomo, Y. \& Davey Smith, G. (1991). Deprivation in infancy or in adult life: which is more important for mortality risk? Lancet 337, 530-534.

Blane, D., Bartley, M. \& Davey Smith, G. (1997). Disease aetiology and socio-economic mortality differentials. European Journal of Public Health (In the Press).

Braddon, F. E. M., Wadsworth, M. E. J., Davies, J. M. C. \& Cripps, H. A. (1988). Social and regional differences in food and alcohol consumption and their measurement in a national birth cohort. Journal of Epidemiology and Community Health 42, 341-349.

Brunner, E. J., Davey Smith, G., Marmot, M., Canner, R., Beksinska, M. \& O'Brien, J. (1996). Childhood social circumstances and psychosocial and behavioural factors as determinates of plasma fibrinogen. Lancet 347, 1008-1013.

Brunner, E. J., Marmot, M. G., White, I. R., O’Brien, J. R., Etherington, M. D., Slavin, B. M., Kearney, E. M. \& Davey Smith, G. (1993a). Gender and employment grade differences in blood cholesterol, apolipoproteins and haemostatic factors in the Whitehall II study. Atherosclerosis 102, 195-207.

Brunner, E. J., Nicholson, A. \& Marmot, M. G. (1993b). Trends in central obesity and insulin resistance across employment grades. Journal of Epidemiology and Community Health 47, 404 405 (Abstr).

Cade, J. E., Barker, D. J. P., Margetts, B. M. \& Morris, J. A. (1988). Diet and inequalities in health in three English towns. British Medical Journal 296, 1359-1362.

Child Poverty Action Group (1996). Poverty: The Facts. London: CPAG.

Davey Smith, G., Bartley, M. \& Blane, D. (1990a). The Black report on socio-economic inequalities in health 10 years on. British Medical Journal 301, 373-377.

Davey Smith, G., Bartley, M. \& Blane, D. (1994a). Explanations for socio-economic differentials in mortality: evidence from Britain and elsewhere. European Journal of Public Health 4, 131-144.

Davey Smith, G., Carroll, D., Rankin, S. \& Rowan, D. (1992). Socio-economic differentials in mortality: evidence from Glasgow graveyards. British Medical Journal 305, 1554-1557.

Davey Smith, G. \& Egger, M. (1993). Socio-economic differentials in wealth and health. British Medical Journal 307, 1085-1086.

Davey Smith, G., Hart, C., Blane, D., Gillis, C. \& Hawthorne, V. (1997). Socioeconomic position over the lifecourse and mortality. British Medical Journal (In the Press). 
Davey Smith, G., Hart, C., Hole, D., Gillis, C., Watt, G. \& Hawthorne, V. (1994b). Education and occupational social class: which is the more important indicator of mortality risk? Journal of Epidemiology and Community Health 48, 500 (Abstr).

Davey Smith, G. \& Kuh, D. (1996). Does early nutrition affect later health? Views from the 1930s and 1980s. In The History of Nutrition in Britain in the Twentieth Century: Science, Scientists and Politics [D. Smith, editor]. Routledge.

Davey Smith, G. \& Marmot, M. G. (1991). Trends in mortality in Britain: 1920-1986. Annals of Nutrition and Metabolism 35, Suppl. 1, 53-63.

Davey Smith, G. \& Morris, J. (1994). Increasing inequalities in the health of the nation. British Medical Journal 309. 1453-1454.

Davey Smith, G. \& Shipley, M. J. (1991). Confounding of occupation and smoking: its magnitude and consequences. Social Science and Medicine 32, 1297-1300.

Davey Smith, G., Shipley, M. J. \& Rose, G. $(1990 \mathrm{~b})$. The magnitude and causes of socio-economic differentials in mortality: further evidence from the Whitehall study. Journal of Epidemiology and Community Health 44 , $260-265$

Department of Health (1995). Variations in Health: What can the Department of Health and the NHS do? London: Department of Health.

Department of Health (1996). Low Income, Food, Nutrition and Health: Strategies for Improvement. London: Department of Health.

Dowler, E. (1996). Women and food in poor families: focus for concern? In Focus on Women: Nutrition and Health, pp. 69-81 [J. Buttriss and K. Hyman, editors]. London: National Dairy Council.

Dowler, E. \& Calvert, C. (1995). Nutrition and Diet in Lone-parent Households in London. London: Family Policy Studies Centre.

Eachus, J., Williams, M., Chan, P., Davey Smith, G., Grainge, M., Donovan, J. \& Frankel, S. (1996). Deprivation and cause-specific morbidity: evidence from the Somerset and Avon Survey of Health. British Medical Joumal 312, 287-292.

Engels, F. (1845). The Condition of the Working Class in England, $1987 \mathrm{ed}$. Harmondsworth: Penguin.

Fehily, A. M., Phillips, K. M. \& Yarnell, J. W. G. (1984). Diet, smoking, social class, and body mass index in the Caerphilly Heart Disease Study. American Journal of Clinical Nutrition 40, 827-833.

Folsom, A. R. Burke, G. K., Ballew, C., Jacobs, D. R., Haskell, W. L. \& Donahue, R. P. (1989). Relation of body fatness and its distribution to cardiovascular risk factors in young blacks and whites. American Journal of Epidemiology 130, 911-924.

Glyn, A. \& Miliband, D. (1994). Paying for Inequality: The Economic Cost of Social Injustice. London: Rivers Oram Press.

Greaves, J. P. \& Hollingsworth, D. F. (1966). Trends in food consumption in the United Kingdom. World Review of Nutrition and Dietetics 6, 354-389.

Gregory, J., Foster, K., Tyler, H. \& Wiseman, M. (1990). The Dietary and Nutritional Survey of British Adults. London: H. M. Stationery Office.

Guha, S. (1994). The importance of social intervention in England's mortality decline: the evidence reviewed Social History of Medicine 7, 89-113.

Gunnell, D., Davey Smith, G., Frankel, S., Nanchahal, K., Braddon, F. E. M., Pemberton, J. \& Peters, T. J. (1996). Childhood leg length and adult mortality - follow up of the Carnegie (Boyd Orr) Survey of diet and growth in pre-war Britain. Joumal of Epidemiology and Community Health (In the Press).

Harding, S. (1995). Social class differences in mortality of men: recent evidence from the OPCS Longitudinal Study. Population Trends 80, 31-37.

Hart, C., Davey Smith, G., Blane, D., Hole, D., Gillis, C. \& Hawthorne, V. (1995). Social mobility, health, and cardiovascular mortality. Journal of Epidemiology and Community Health 49, 552 (Abstr).

James, J. (1995). Nutrition in the normal infant: opportunities in primary care. In Nutrition and Child Health, pp. 43-49 [D. P. Davies, editor]. London: Royal College of Physicians of London.

Johansson, L., Drevon, C. A. \& Bjørneboe, G. E. (1996). The Norwegian diet during the last hundred years in relation to coronary heart disease. European Journal of Clinical Nutrition 50, 277-283.

Johansson, S. R. (1994). Food for thought: rhetoric and reality in modern mortality history. Historical Methods 27, 101-125.

Jones, H. B. (1956). A special consideration of the ageing process, disease and life-expectancy. Advances in Biology and Medical Physics 4, 281-337.

Koskinen, S. (1994). Origins of Regional Differences in Mortality from Ischaemic Heart Disease in Finland. National Research and Development Centre for Welfare and Health Search Report no. 41. Helsinki: NAWH.

Kuczmarski, R. J., Flegal, K. M. Campbell, S. M. \& Johnson, C. L. (1994). Increasing prevalence of overweight among US adults. The National Health and Nutrition Examination Surveys, 1960-1991. Journal of the American Medical Association 272, 205-211.

Kuh, D. \& Davey Smith, G. (1993). When is mortality risk determined? Historical insights into a current debate. Social History of Medicine 6, 101-123.

Leitch, I. (1951). Growth and health. British Journal of Nutrition 5, 142-151. 
Lobstein, T. (1995). The increasing cost of a healthy diet. Food Magazine 31, 17.

Lynch, J. W., Kaplan, G. A. \& Salonen, J. T. (1996). Why do poor people behave badly: variation in adult health behaviours and psychosocial characteristics by stages of the socio-economic lifecourse. Social Science and Medicine (In the Press).

McCarron, P. G., Davey Smith, G. \& Womersley, J. J. (1994). Deprivation and mortality: increasing differentials in Glasgow, 1979-1992. British Medical Joumal 309, 1481-1482.

McKeigue, P. M., Shah, B. \& Marmot, M. G. (1991). Relation of central obesity and insulin resistance with high diabetes prevalence and cardiovascular risk in South Asians. Lancet 337, 382-386.

McKeown, T. (1988). The Origins of Human Disease. Oxford: Blackwell.

Mare, R. D. (1990). Socio-economic careers and differential mortality among older men in the United States. In Measurement and Analysis of Mortality: New Approaches, pp. 362-387 [J. Vallin, S. D'Douza and A. Palloni editors]. Oxford: Clarendon Press.

Marmot, M. G., Davey Smith, G., Stansfeld, S., Patel, C., North, F., Head, J., White, I., Brunner, E. \& Feeney, A. (1991). Inequalities in health twenty years on: the Whitehall II study of British Civil Servants. Lancet 337, 1387-1394.

Morgan, M., Heller, R. F. \& Swerdlow, A. (1989). Changes in diet and coronary heart disease mortality among social classes in Great Britain. Journal of Epidemiology and Community Health 43, 162-167.

Morris, J. N. (1956). Fats and disease. Lancet i, 687-689.

Najman, J. (1993). Health and poverty: past, present and prospects for the future. Social Science and Medicine 2 , 157-166.

Nutrition and Physical Activity Task Forces (1995). Obesity: Reversing the Increasing Problem of Obesity in England, pp. 1-34. London: Department of Health.

Pamuk, E. R. (1985). Social class inequality and mortality from 1921-1971 in England and Wales. Population Studies 39, 17-31.

Phillimore, P., Beattie, A. \& Townsend, P. (1994). Widening inequality of health in Northern England, 1981-91. British Medical Journal 308, 1125-1128.

Pryer, J. A., Brunner, E. J., Elliott, P., Nichols, R., Dimond, H. \& Marmot, M. G. (1995). Who complied with COMA 1984 dietary fat recommendations among a nationally representative sample of British adults in 19867 and what do they eat? European Journal of Clinical Nutrition 49, 718-728.

Rimm, E. B., Ascherio, A., Giovannucci, E., Spiegelman, D., Stampfer, M. J. \& Willett, W. C. (1996). Vegetable, fruit, and cereal fibre intake and risk of coronary heart disease among men. Journal of the American Medical Association 275, 447-451.

Rowett Research Institute (1955). Family Diet and Health in Pre-war Britain. Dunfermline: Carnegie United Kingdom Trust.

Salhi, M., Caselli, G., Duchêne, J., Egidi, V., Santini, A., Thiltgés, E. \& Wunsch, G. (1995). Assessing mortality differentials using life histories: a method and applications. In Adult Mortality in Developed Countries: From Description to Explanation, pp. 57-79 [A. Lopez, G. Caseilli and T. Vakonen, editors]. Oxford: Clarendon Press.

Sooman, A., Macintyre, S. \& Anderson, A. (1993). Scotland's health: A more difficult challenge for some? Health Bulletin 51, 276-284.

Stephen, A. M. \& Sieber, G. M. (1994). Trends in individual fat consumption in the UK 1900-1985. British Journal of Nutrition 71, 775-788.

Szreter, S. (1988). The importance of social intervention in Britain's mortality decline 1850-1940: a reinterpretation of the role of public health. Social History of Medicine 1, 1-37.

Tannenbaum, A. (1947). Effects of varying caloric intake upon tumor incidence and tumor growth. Annals of the New York Academy of Sciences 49, 5-18.

Travers, K. D. (1996). The social organisation of nutritional inequities. Social Science and Medicine 43, 543-553.

Trenchard, T. (1977). Fat consumption - long-term trends. Health and Hygiene I, 77-82.

Vague, J. (1956). The degree of masculine differentiation of obesities: a factor determining predisposition to diabetes, atherosclerosis, gout, and uric calculous disease. American Journal of Clinical Nutrition 4, $20-34$.

Valkonen, T. (1987). Male mortality from ischaemic heart disease in Finland, relation to region of birth and region of residence. European Joumal of Population 3, 61-83.

World Health Organization Expert Committee on Prevention of Coronary Heart Disease (1982). Prevention of Coronary Heart Disease. WHO Technical Report Series no. 678. Geneva: WHO.

Williams, R. (1994). Medical, economic and population factors in areas of high mortality: the case of Glasgow. Sociology of Health and Illness 16, 143-181.

Winter, J. M. (1988). Public health and the extension of life expectancy in England and Wales 1901-1960. In The Political Economy of Health and Welfare, pp. 184-203 [M. Keynes, D. A. Coleman and N. H. Dimsdale, editors]. London: Macmillan.

Wrigley, E. A. \& Schofield, R. S. (1981). The Population History of England, 1541-1871. Cambridge, Mass: Harvard University Press. 